\title{
Prêmio Nobel de Literatura 2021 a um autor africano
}

Foi com grande espanto que o nome do ganhador do prêmio Nobel de Literatura de 2021 apareceu nas manchetes dos jornais. Pouco se sabia sobre Abdulrazak Gurnah, 74 anos, o 118. ${ }^{\circ}$ laureado na história do Nobel da Literatura. Há mais de três décadas que nenhum escritor africano negro era reconhecido com aquele prêmio, sendo o nigeriano Wole Soyinka agraciado em 1986.

Considerado pela agência France Presse como um galardão "historicamente muito ocidental" (de toda a história do Nobel da Literatura, atribuído pela primeira vez em 1901, mais de $80 \%$ foram autores europeus ou norte-americanos), a última vez que a Academia Sueca distinguiu um autor africano com o Nobel da Literatura foi em 2003, ao sul-africano J.M. Coetzee.

Abdulrazak Gurnah, apesar de desconhecido do grande público, entretanto, já havia sido apontado pela crítica como um autor de grande qualidade: sua obra: Paradise, lançada em 1994, foi nomeada para Booker Prize, a mais significativa premiação para ficção em língua inglesa e para o Whitebread Prize, assim como Junto ao mar também esteve na lista dos indicados.

Foram também muito elogiados pela crítica os romances $B y$ the sea (2001), Desertion (2015) e os mais recentes Gravel heart (2017) e Afterlives (2020).

De refugiado a ganhador do Nobel

Nascido em 1948 na ilha de Zanzibar, na Tanzânia, Abdulrazak Gurnah mudou-se para o Reino Unido nos anos 1960 com o estatuto de refugiado. Começou a escrever aos 21 anos e entrou para a carreira acadêmica, 
onde foi, até sua recente aposentadoria, professor de Inglês e de Literatura Pós-colonial na Universidade de Kent.

Apesar do Swahili ser a sua primeira língua, Gurnah cedo começou a escrever em inglês, fazendo desta a sua ferramenta literária. De acordo com a Academia Sueca, parte substantiva da Gurnah — que consiste em 10 romances e vários contos — debruça-se sobre a condição do refugiado, focalizando a dificuldade entre manter a identidade que se carrega e a nova que é preciso criar numa novo cenário, com outros costumes e modelos, e tenta combater a perspectiva eurocêntrica e colonial, destacando a das populações indígenas, dedicando-se a uma "comovedora descrição dos efeitos do colonialismo na África e do destino dos refugiados, no abismo entre diferentes culturas e continentes".

Segundo o porta voz da Academia Sueca, Anders Olsson, "a dedicação de Gurnah à verdade e a sua aversão à simplificação são impressionantes. Isto pode torná-lo sombrio e intransigente, ao mesmo tempo que segue os destinos dos indivíduos com grande compaixão e compromisso inflexível".

Os seus romances, ainda segundo a Academia, "recuam das descrições estereotipadas" e abrem o olhar do leitor para uma África Oriental culturalmente diversificada, desconhecida de muitos em outras partes do mundo. "[Seus] personagens se encontram em um hiato entre culturas e continentes, entre uma vida que existia e uma vida que surge; em um estado de insegurança que nunca pode ser resolvido."

Que a premiação de Abdulrazak Gurnah propicie novos olhares sobre as questões africanas e um maior conhecimento à excelente literatura feita naquele continente. 